\title{
In de eeuwen der eeuwen, (t)amen
}

\section{Georges Martyn}

\section{Citer ce document / Cite this document :}

Martyn Georges. In de eeuwen der eeuwen, (t)amen. In: Revue belge de philologie et d'histoire, tome 70, fasc. 4, 1992. Histoire médiévale, moderne et contemporaine - Middeleeuwse, moderne en hedendaagse geschiedenis. pp. 921-941; doi : https://doi.org/10.3406/rbph.1992.3861

https://www.persee.fr/doc/rbph_0035-0818_1992_num_70_4_3861

Fichier pdf généré le 16/04/2018 


\section{In de eeuwen der eeuwen, (t)amen ...}

Georges MARTYN

Over edicten, eeuwige edicten en andere wetgevingsterminologie in de zestiende en zeventiende eeuw.

In het Belgisch Tijdschrift voor Filologie en Geschiedenis vinden we in 1925 en 1975 bijdragen over de terminologie waarmee onze oude wetgevende akten worden aangeduid. Paul Bonenfant (1) bestudeert de wetgeving van MariaTheresia. Hij onderscheidt, steunend op De Neny ( $\left.{ }^{2}\right)$, legislatieve en administratieve ordonnanties. De legislatieve zijn in de vorm van „lettres patentes" gegoten en worden gepubliceerd. De belangrijkste verdienen de naam ,édit”. Administratieve akten daarentegen, met namen als „royale dépêche”, "décret” en „lettre”, ondergaan geen formele publicatie. „Decreet” heeft de zeer specifieke betekenis van een mededeling van de gouverneur aan de collaterale raden. Jean-Marie Cauchies $\left({ }^{3}\right)$ belicht de ordonnanties van de Boergondische hertogen. Hij maakt een nomenclatuur van drie groepen termen. Deze groepen onderscheiden zich van elkaar doordat ze ten eerste wijzen op een juridische werkelijkheid met bevelskarakter (,ordonnance, édit, mandement”) of ten tweede op een bepaalde wijze van publiceren (,criée”) of formuleren (,défense, modération"). De derde groep tenslotte verzamelt een aantal minder eenduidige termen (,lettres"). Voor de eerste groep komt hij tot het besluit dat het gebruik der termen ,ne répond à aucune règle tacitement admise, ni à plus forte raison prescrite par les usages formels ou juridiques du temps". Ook van de tweede

(1) P. Bonenfant, La terminologie des actes officiels sous Marie-Thérèse, in Belgisch Tijdschrift voor Filologie en Geschiedenis, IV, 1925, p. 141-147.

(2) P. DF. Neny, Mémoires historiques et politiques sur les Pays-Bas autrichiens et sur la constitution tant interne qu'externe des provinces qui les composent, Neuchâtel, 1784.

(3) J.-M. CAuchies, La terminologie dans les ordonnances des ducs de Bourgogne, in Belgisch Tijdschrift voor Filologie en Geschiedenis, LIII, 1975, p. 402-418. Prof. Cauchies is zo vriendelijk geweest onze kopij na te lezen en enkele belangrijke correcties en aanvullingen te verstrekken. Graag wil ik hem hiervoor mijn oprechte dank betuigen. 
groep mogen we de benamingen niet in hun strikte, oorspronkelijke betekenis interpreteren. De terminologie van de derde groep is al even wisselvallig. In zijn slotwoorden waarschuwt de auteur dan ook voor subjectiviteit en anachronisme bij de bestudering van deze oude wetteksten.

In onderhavig artikel pogen we het hiaat op te vullen tussen de twee reeds onderzochte perioden. We vragen ons af of er een logische lijn kan getrokken worden tussen de vaststellingen van Cauchies enerzijds en Bonenfant anderzijds. We zouden dus een overgang moeten vaststellen van nagenoeg volledig willekeurig gebruik van termen naar wel bepaalde afspraken hieromtrent.

Voor dit onderzoek kan tegenwoordig gesteund worden op de nagenoeg integraal uitgegeven wetgeving van de zestiende tot de achttiende eeuw. Naast de legislatieve bronnen, bieden ook de contemporaire juridische doctrine alsook de oude taalwetenschap belangrijke elementen aan. Nadat we de onderzoeksperiode gedefinieerd hebben en het onderzochte materiaal beschreven, zullen we eerst bepalen wat we onder wetgevende akten begrijpen. Aan de hand van voorbeelden als plakkaat en ordonnantie zoeken we dan etymologische verklaringen. Mogelijke hypothesen, alsook bevindingen uit rechtsvergelijkend onderzoek zullen we echter moeten weerleggen na een confrontatie met het overvloedig en gecombineerd gebruik van allerlei synoniemen, waarvan we enkele voorbeelden belichten. Op zoek naar een evolutie binnen dit termengeheel stellen we een (her)opbloei van „edicten" vast. Voor een onderscheid tussen eeuwige en gewone edicten verzamelen we elementen van verklaring uit het Romeins recht, de vorm en de inhoud der akten. We zullen moeten besluiten dat dit verschil, net als het onderscheid met andere wetsbenamingen, juridisch verwaarloosbaar is. De evolutie naar een netjes afgelijnd begrippenarsenaal is in de onderzochte periode slechts in de kiem aanwezig.

Chronologisch bakenen we het onderzoeksterrein af bij de troonsbestijging van Karel V (1506) aan de ene kant en het einde van de regering van de aartshertogen (1621) aan de andere. Voor de zestiende eeuw houden we ons aan een diagonale lezing van de tekstuitgaven van de Koninklijke Commissie voor de Uitgave van de Oude Wetten en Verordeningen van België. De ordonnanties uit de regeerperiode van de aartshertogen (1598-1621) daarentegen worden nauwgezet gedissecteerd. In beide gevallen komen we tot de vaststelling dat op de regesten boven de gepubliceerde wetteksten als terminologische reflectie van de tekst zelf niet mag vertrouwd worden. Gilissen deed dat in 1958 wel $\left({ }^{4}\right)$. Hij baseerde zich voor zijn statistisch overzicht van de centrale wetgeving op de tekstuitgaven van de Koninklijke Commissie en op de eveneens door de Commissie gepubliceerde - chronologische lijsten. Meer dan veertienduizend wetgevende akten klasseerde hij per regeringsperiode, naar

(4) J. Gir.Issen, Essai statistique de la législation en Belgique de 1507 à 1794, in Revue du Nord, XL, 1958, p. 431-435. 
behandelde materie, naar legifererende overheid, alsook naar hun benaming. Voor de terminologie steunde hij op de regesten van de uitgaven. Deze vlaggen blijken echter vaak de lading niet te dekken. Gilissen had nochtans ook zelf vastgesteld dat „dans le texte de la plupart des actes législatifs, on ne trouve aucun terme servant à désigner l'acte. Dans d'autres, par contre, on en trouve deux, trois ou quatre, ..." (5). In vele gevallen heeft het van de willekeur van de (meestal de eerste) tekstuitgever afgehangen onder welke benaming een "wet” de geschiedenis zou in gaan. Zo stelde Cauchies vast dat zelfs op het moment van de afkondiging een zelfde tekst op verschillende plaatsen onder verschillende benamingen kan voorkomen. De ambtenaar die moet instaan voor de lokale publicatie, maakt daarvan gewag in zijn rekeningen. Hij gebruikt hiervoor niet steeds dezelfde namen als waarvan in de akten zelf sprake.

Voor ons is het heden ten dage een uitgemaakte zaak dat elke soort wet zijn eigen naam heeft. Het volstaat de recente grondwetswijzigingen en de bijzondere wetten naar aanleiding van de staatshervorming erop na te lezen. We vinden er juridisch gesanctioneerde onderscheiden tussen wetten, decreten en ordonnanties. Een speciaal bevoegd Arbitragehof waakt over het juist gebruik der termen. In de zestiende en zeventiende eeuw is dit ondenkbaar. Wetten hebben er nu eens verschillende namen, dan weer zelfs helemaal geen („dese ieghenwoirdighe”). In de gewone situatie draagt de tekst één naam. We zullen zien dat we aan deze benaming geen exclusieve wel bepaalde juridische betekenis mogen toekennen. In de chronologische lijsten (of de regesten) vinden we bijvoorbeeld verschillende malen de term "edict", terwijl in de betrokken wettekst zelf niet „edict”, maar "ordonnantie" gebruikt wordt $\left({ }^{6}\right)$. Helemaal onbetrouwbaar wordt het regest als in het corpus van de tekst verschillende termen door of naast elkaar gebruikt worden : ordonnantie, decreet, edict, pragmatieke, bevel, mandement, constitutie, plakkaat, ...

Al deze soorten hebben gemeen dat ze van algemene strekking zijn. Dit wil niet noodzakelijk zeggen dat ze daarom ook voor iedereen gelden of aangelegenheden regelen die iedereen aanbelangen. Zeker voor de Nieuwe Tijd, wanneer de centrale wetgeving voor vele rechtsmateries (in de eerste plaats die van het privaatrecht) nog in haar kinderschoenen staat, wanneer nog tal van corporatistische en etataire verhoudingen bestaan en het onderscheid publiek/privaatrecht bijna niet bekend is, is het nagenoeg onmogelijk te bepalen wat onder ,algemene strekking” moet begrepen worden. De Koninklijke Commissie voor de Uitgave van de Oude Wetten en Verordeningen van

(5) Eod., p. 433.

(6) Enkele voorbeelden : de verordening van de laatste februari 1508 (1509 n.s.) over de gerechtsdeurwaarders bij de Grote Raad van Mechelen (C. Laurenr (ed.), Recueil des ordonnances des Pays-Bas, reeks 2, dl. 1, Brussel, 1893, p. 72-74) of die van 19 juni 1509 inzake pooiers en vagebonden (Eod., p. 97-104). 
België is nooit tot een hanteerbare definitie gekomen $\left({ }^{7}\right)$. Zo een definitie is a posteriori voor ons al moeilijk, ondanks ons arsenaal aan rechtstheoretische begrippen en constructies. Des te minder lijkt het aan te nemen dat de zestiende-eeuwse wetgever over een weloverwogen en afgelijnd glossarium beschikte.

Etymologisch is het mogelijk voor elke term naar zijn specifieke en orginele betekenis terug te gaan. Daarvoor beschikken we over tal van algemene, juridische of etymologische woordenboeken $\left({ }^{8}\right)$. Vaak vinden we ook achteraan juridische werken een glossarium of verklarende woordenlijst. Vooral dit type bron zou ons een en ander moeten leren. G. Van Dievoet belichtte onlangs nog het „Vocabulaer" uit een editie van 1503 van de Nederlandse vertaling van de Somme rural van Jehan Boutillier $\left({ }^{9}\right)$. Noch in dergelijke lijsten, noch in algemene taalwerken vinden we aanduidingen dat de termen gedurende een lange tijdspanne hun originele betekenis exclusief behouden hebben. De meest gebruikte (Gilissen telde er 1.594) en meest algemene term, die zoals Cauchies vaststelt ook al in de vorige periode geen exclusieve betekenis had, is „ordonnantie” („ordonnance”). Misschien mogen we het gebruik ervan in de zestiende tot achttiende eeuw vergelijken met ons hedendaagse gebruik van ,wet". Met „wet" kunnen we vandaag alle kanten uit, er zijn formele wetten en materiële wetten, er is de betekenis van wet als beding, enz ... In de Middeleeuwen en Nieuwe Tijd komt "wet" in deze betekenissen nagenoeg

(7) Zie onder andere het verslag van de $52^{e}$ zitting (van 27 november 1886, in Handelingen van de Koninklijke Commissie voor de uitgave der oude Wetten en Verordeningen van België, VII, 1906, p. 38-39) : „M. Laurent signale à la Commission que la liste chronologique des ordonnances dc 1506 à 1555 renferme plusieurs documents qui, à son avis, sont dépourvus du caractère de généralité et de permanence que doit revêtir l'ordonnance proprement dite". In de zelfde handelingen lezen we iets verder (zitting van 6 februari 1912, Eod., IX, 19113, p. 366) : „M. le Président (J. Lameere) est d'avis qu'il faut s'en tenir surtout à l'importance de la matière traitée dans l'ordonnance. L'éditeur jugera ...". Paul Bonenfant (Rapport sur la publication de la liste chronologique des ordonnances bourguignonnes, Eod., XVI, 1950, p. 1316) bepaalt als verordening : „tous les actes manifestant la volonté du pouvoir souverain en tant que tel, à l'exception de ceux d'un intérêt exclusivement particulier".

(8) We gebruikten voornamelijk A. DAUZAT, Dictionnaire étymologique de la langue française, Parijs, 1938 ; F. GoDEFROY, Dictionnaire de l'ancienne langue française et de tous ses dialectes $d u \quad x^{e}$ au $x v^{e}$ siècle, $10 \mathrm{dln}$., heruitgave Vaduz, 1965; W. WARTBURG, Französisches Etymologisches Wörterbuch, 14 dln., Tübingen, 1946-1961 met aanvullingen tot fasc. 151 (1990). E. Huciver, Dictionnaire de la langue française $d u x_{v I^{e}}$ siècle, 7 dln., Parijs, 1925-1967. Deze woordenboeken zijn niet specifiek juridisch. Vele termen hebben dan ook tal van betekenissen die niet voor ons onderzoek in aanmerking komen. „Ordonnance” heeft bij GODEFROY bijvoorbeeld 24 betekenissen.

(9) G. VAN DiEvoET, Een weinig bekende verklarende lijst van Nederlandse rechtstermen van Franse of Latijnse oorsprong van het begin van de l6de eeuw, in Liber amicorum Prof. Dr. Jozef Van Haver, Brussel, 1991, p. 509-534. In dit artikel wordt naar een tiental woordenlijsten uit de door ons onderzochte periode verwezen. 
niet voor (Gilissen neemt het niet op zijn overzicht), behalve in latijnse juridische werken. Gebruik makend van de Romeinse begrippen vinden we er lex in de zin van beding en vooral in de uitdrukking vigor legis. Lex wordt dan de verzamelnaam voor alle akten die de wil van de vorst uitdrukken. Of dit dan bepalingen zijn van algemene strekking, dan wel zeer particuliere voorschriften, speelt geen rol $\left({ }^{10}\right)$. „Ordonnance” of "ordinantie” zijn mogelijk de volkstaalsynoniemen geworden voor lex, omdat "loi" en ,wet" in die tijd de specifieke betekenis hebben van recht door de rechter gevonden, zoals in de uitdrukking ,wet doen”. De etymologie van ordonnantie maakt zijn algemene en gewone betekenis duidelijk. Het is een tekst waarmee de wetgever of de rechter of zelfs het rechtssubject (cfr. i.) iets beveelt of ordonneert, met andere woorden orde op zaken stelt. Vooral in de werkwoordsvorm „ordonneren, ordonnons" komt deze terminologie in bijna alle teksten voor doorheen de Middeleeuwen en Nieuwe Tijd. Meestal gaat „ordonnantie” vergezeld van andere termen, die zowel synoniemen kunnen zijn (,ordonneren ende statueren” bijvoorbeeld) als nadere verklaringen (,ordonneren ende verbieden” bijvoorbeeld). Ordonnanties zijn nu eens wetgevende akten, waarbij we deze omschrijving dan in de meest brede zin moeten interpreteren, dan weer zijn het individuele rechtshandelingen. Als wetgevende akte slaat de term meestal op een hele wet, doch vaak ook op individuele artikelen. Als synoniemen komen ze nogal eens samen voor : "lesdicts ordonnances ou articles" ('). Wanneer een artikel verschillende regels voorschrijft, kan „ordonnantie” zelfs slaan op elk van de onderscheiden bepalingen (12). Als gebruik van de term „ordonnantie" voor andere, individuele rechtshandelingen, kunnen we bijvoorbeeld verwijzen naar de betekenis van rechterlijke beslissing. Ook de rechter ordonneert immers in een concreet geschil. Een andere toepassing van de term is de definitie van testament als „ordonnance de dernière volonté” of „ordinantie van lesten wille" $\left({ }^{13}\right)$.

Paul Bonenfant wijdde een studie aan de ,placards" van Karel V ( $\left.{ }^{14}\right)$. Steunend op de franse traditie haalt hij enkele mogelijke verklaringen aan.

(10) Zie de opinie van François VAN Den Zype, noot 15.

(11) Zie bijvoorbeeld de vraag om interpretatie van „lesdicts ordonnances ou articles 12. \& 19., van het Eeuwig Edict van 12 juli 1611, uitgaande van de Raad van Luxemburg op 24 maart 1623 (gepubliceerd in J.-B. CHRISTYN, Brabandts recht dat is generale costumen vanden lande ende hertoghdomme van Brabandt midtsgaders van het hertoghdom van Limborgh stede ende lande van Mechelen met verscheyde ordonnantien reglementen, statuten, ende manieren van procederen, dl. 2, Antwerpen, 1682 ,p. 1189).

(12) Zo lezen we in een brief van 17 november 1631 uitgaande van de Raad van Namen : „qu'iceluy article (art. 19 Eeuwig Edict 12 juli 1611) contient deux ordonnances, l'une ... ; l'autre ..." (eod., p. 1207).

(13) Zie Artikel 37 van het Eeuwig Edict van 12 juli 1611 bijvoorbeeld.

(14) P. Bonrntant, A propos des 'Placards' de Charles-Quint, in Miscellanea Historica in honorem Alberti De Meyer, Leuven, 1946, II, p. 781-790. 
De etymologische verklaring dat een plakkaat een stuk is dat moet publiek gemaakt worden bij wijze van ,aanplakking”, ligt wellicht iets te zeer voor de hand. Volgens de diplomatieke theorie vervolgens zou het in oorsprong gaan om een niet geplooid stuk. Bonenfant verwerpt beide hypothesen en zoekt de origine van het woord in "l'apposition d'un sceau plaqué". Vanaf het midden van de zestiende eeuw, nog steeds volgens deze historicus, ontstaat er verwarring met de idee van afficheren. De term wordt dan gebruikt van zodra er geafficheerd wordt, ongeacht de diplomatieke vorm waarin de soeverein zijn wil te kennen geeft. Tegen het einde van het Ancien Regime, of wellicht al vroeger, is plakkaat dan ook synoniem geworden van ordonnantie. Een niet door Bonenfant belichte hypothese legt een verband tussen „plakkaat” en placitum, de juridische basis voor de geldingskracht van de wet. De uitgevaardigde bepalingen moeten nageleefd worden omdat dat de wil van de soeverein is. In de absolutistische theorie van de Nieuwe Tijd werd dit Romeinse principe, quod principi placuit, uitvoering bestudeerd door de rechtsgeleerden (15). Zij waren nauw betrokken bij het wetgevend werk, vooral in de Geheime Raad, en hebben ongetwijfeld hun stempel nagelaten op de redactie (16). Gilissen telde meer dan 2.000 keren "Car ainsi nous plaît-il". 97\% ervan waren teksten uitgaande van de souverein. Zijn de aangehaalde stellingen van Bonenfant niet exhaustief, het is vooral gevaarlijk ze vanuit de keizerlijke kanselarij te veralgemenen. G. Immel ( ${ }^{17}$ ) schrijft : „Was für das eine Territorium gilt, ist nicht notwendig auch für das andere massgebend". Zo beweert hij dat in Frankrijk een „ordonnance” een aanzienlijke rechtsmaterie regelt ( $\left.{ }^{18}\right)$, terwijl „édits” slechts op een beperkte materie betrekking hebben. We vinden deze verklaring ook in de meeste van de hoger aangehaalde

(15) Zie o.a. F. Van Den Zype of Zypaeus, Notitia iuris belgici, Antwerpen, 1675, p. 16 : Leges, constitutiones, edicta, ordinationes, placita ad principem hodie pertinent ex lege regia en p. 18 : quod Principi placet legis habet vigorem: sive edixerit, sive rescripserit, sive interlocutus.

(16) We moeten ons hier ongetwijfeld hoeden voor „Hineininterpretierung” en verwisseling van oorzaak en gevolg. Worden uitdrukkingen als "car ainsi nous plaît-il" en „placita" populair omdat ze goed aansluiten op de traditionele benaming „plakkaat” ? Of wordt „plakkaat” meer en meer gebruikt omdat de term zo goed aansluit op de terminologie van het geleerd recht ? Beide waren voor elkaar wellicht een katalysator.

(17) G. Immei., Typologie der Gesetzgebung des Privatrechts und Prozessrechts, in H. CoING (ed.), Handbuch der Quellen und Literatur der neueren europäischen Privatrechtsgeschichte, II, 2, Munchen, 1976, p. 3-96, citaat op p. 4.

(18) W. WII.HEI.M, Gesetzgebung und Kodifikation in Frankreich im 17. und 18. Jahrhundert, in Ius Commune, I, 1967, p. 241-270 plaatst de oorsprong van de franse „ordonnances" bij de „ordonnances de réformation”, die sinds de $14^{\mathrm{e}}$ eeuw uitgevaardigd werden en betrekking hadden op verschillende (eerder publiekrechtelijke) materies. Het waren meestal antwoorden op "cahiers de doléances". Als laatste noemt hij de Code Michau van 1629. Zie hierover F. OiliviER MARTIN, Histoire du droit français des origines à la Révolution, Parijs, 1951, p. 353. 
woordenboeken en bij de Franse diplomatisten $\left({ }^{19}\right)$. Lager zullen we vaststellen dat dit voor onze streken zeker geen waarheid is. Het eeuwig edict van 12 juli 1611 bijvoorbeeld kan bijna een wetboek genoemd worden ${ }^{20}$ ). Er worden diverse materies van publiek en privaatrecht in geregeld. Vele onderwerpen van dit ,édit" vinden hun analoge tegenhangers in enkele Franse „ordonnances” van de zestiende en zeventiende eeuw. De volledige titel, zoals hij voorkomt in de officiële gedrukte uitgave ${ }^{21}$ ), vermeldt daarenboven twee benamingen naast elkaar : „Ordonnance et édict perpétuel” of „ordinancie ende eeuwigh edict". In de authentieke interpretatie van 27 augustus 1612, noemt de vorst de ordonnantie van 12 juli 1611 zelfs "placcart et edict” (22).

In vergelijking met Frankrijk hanteerde het Zuidnederlandse centrale bestuur dus duidelijk een minder rigoureuze terminologie. In Spanje verschilt de benaming al naargelang de wet tot stand komt op voorstel of met goedkeuring van de standen. In de eerste paragrafen van de Zuidnederlandse wetten vinden we ook telkens refertes naar de remonstranten of adviseurs van de betrokken bepalingen. We vinden echter geen vaste correlaties tussen deze personen en instanties en de benaming van de akte. Al deze rechtsvergelijkende

(19) Zie bijvoorbeeld A. GiRY, Manuel de diplomatique, New York, 1983, p. 776. Deze auteur geeft nog meer verschilpunten. Een ordonnantie zou van algemeen belang zijn, het hele koninkrijk bestrijken, meestal op verzoek van de Staten gegeven zijn en verschillende materies regelen, vooral dan de justitie. Edicten daarentegen zouden van ondergeschikt belang zijn, voor een bepaald gewest gelden, door de koning motu proprio gegeven zijn en slechts een bepaalde niet-juridische aangelegenheid regelen.

$\mathrm{Nu}$ we vaststellen dat deze onderscheiden voor de Nederlanden zeker niet gelden, moeten we ons wellicht ook afvragen in welke mate de beweringen van Giry wel onwrikbaar zijn, ook in Frankrijk. Beschrijft Giry de werkelijkheid of maakt hij slechts een diplomatiek-theoretisch onderscheid ? Veldwerk zal dit nog moeten uitwijzen. Bij wijze van voorbeeld vermelden we hier slechts een ,ordonnance sur la transmission des offices" (1566), aangaande een beperkte materie dus, en een zeer omvangrijk „édit sur la pacification des troubles du royaume, les protestans, les religionnaires fugitifs, la convocation des États-Généraux, etc ..." (1576), zie F. IsAmberT en A. Jourdan (ed.), Recueil général des anciennes lois françaises depuis l'an 420 jusqu'à la révolution de 1789, Parijs, 1821-1833, dl. 14, p. 225 resp. 280-302.

(20) Zie G. Crolsiau, Het Eeuwich Edict tot heter directie in saecken van Justitie in de landen van Herwaertsover, in Wetboek en grondwet in historisch perspectief. Liber amicorum John Gilissen, Antwerpen, 1983, p. 61-76.

(21) Deze werd uigegeven te Brussel door Rutgeer Velpius en Huybrecht Anthoon (,gesworen boecvercoopers en druckers van hare Hoocheden inden gulden Arent by ' $t$ Hoff") in 1611. De Franse en Nederlandse versie werden in boekvorm $(20 \times 15 \mathrm{~cm})$ samen afgedrukt. Deze publicatie is op heden nog in weinig bibliotheken voor handen. In de Koninklijke Bibliotheek te Brussel zijn er nog enkele exemplaren van, nr. II, 60547 heeft (wellicht zeventiende-eeuwse) handgeschreven aanvullingen. Velpius had op 10 juli 1604 het monopolie verkregen op de publicatie der ordonnanties, zie V. Brants (ed.), Recueil, dl. 1, p. 244.

(22) Zie J.-B. Christry, Brahandts recht, dl. 2, p. 1179. De interpretatie van 5 februari 1614 noemt het edict zelfs kortweg „placcart”, eod., p. 1199. 
elementen maken ons dus niet veel wijzer. Voor de Nederlanden komen we, net als Immel, tot de vaststelling dat er geen vaste terminologie is. Ordonnantie, edict, plakkaat, decreet, constitutie, pragmatieke, pragmatieke sanctie, verklaring en andere worden door elkaar gebruikt, ongeacht de wetgever, de behandelde materie, de justiciabelen of het toepassingsgebied. In de door Van Dievoet bestudeerde woordenlijst uit de zestiende eeuw vinden we het onvertaalde latijnse „edictum” verklaard als „generael gebot” en „perpetuele” als „ewelic of te ewigen daghen". Van alle andere hierboven aangehaalde benamingen is er in deze lijst geen spoor.

Zeer markante bewijzen van het feit dat de terminologie niet precies gedefinieerd is, zijn de (meestal lange) verordeningen die in het corpus van de tekst verschillende namen dragen. Bij wijze van voorbeeld belichten we de verordening tegen Luther van 8 mei $1521\left({ }^{23}\right)$. De uitgevers van de tekst noemen deze wet gewoon ,édit de l'empereur". In de tekst zelf vinden we niet minder dan negen synoniemen : „dit ons jeghenwoordich bevel, decreet ende ordonnancie", "verclaren ende discerneren by desen onsen brieven", "desen onse edicte, bevele ende openbaringhe”, „desen onsen edicte ende mandemente”, „by desen statute”, „mandement ende voorghebodt". In tegenstelling tot latere ketterwetten neemt deze wet echter niet de vorm van een eeuwig edict aan, althans niet uitdrukkelijk. De keizer had wel de bedoeling „dat dit zy vaste ende ghestandich, gheduerich ende eeuwich". De combinaties van de verschillende termen blijven niet beperkt tot juxtapositie van synoniemen. We ontmoeten ook combinaties als : „statuons et ordonnons pour édict" $\left({ }^{24}\right)$, ,jonnen, verleenen, octroyeren ende accorderen, ende daertoe voor statuut ende edict eeuwelick geduerende ordonneren, ...” (25), „statuons et déclarons par forme de constitution et édict perpétuel" (26).

Heeft dit barok gebruik van termen een juridische ratio ? Of gaat het eerder om esthetisch gegoochel met woorden eigen aan de administratieve taal van alle tijden en a fortiori aan die van de Zuidnederlandse Nieuwe Tijd? De tweede verklaring is wellicht de juiste. We zien immers dat in andere administratieve stukken uit dezelfde periode ook in zinnen met minder juridische relevantie synoniemen naast elkaar gebruikt worden $\left({ }^{27}\right)$. Ook in notariële

(23) Zie C. Laurent en J. Lamfife (ed.), Recueil, reeks 2, dl. 2, Brussel, 1898, p. 73-83.

(24) Het edict van 14 oktober 1529 over de ketterij bijvoorbeeld, zie J. LAMrE:R: (ed.), Recueil, reeks 2, dl. 2, p. 578-583.

(25) Eeuwig edict van 9 november 1522 betreffende de rechtsmiddelen tegen de uitspraken van de lagere Vlaamse rechtbanken, eod., p. 242-244.

(26) Eeuwig edict van 17 juli 1523 met betrekking tot enkele regels van leenrecht in Brabant en Overmaas, eod., p. 286-288.

(27) In een decreet van 19 juli 1669 met betrekking tot de stilzwijgende hypotheek ten voordele van minderjarigen, lezen we: „Alle welcke disputen, gheschillen ende differentien tot ruste ende welvaren ..., cndc het onderhouden van pais ende vrede ...", zie J.-B. Christyn, Brabandts recht, dl. 2, p. 1211. 
akten vinden we ellenlange opsommingen van synoniemen $\left({ }^{28}\right)$. Evenmin dienen de synoniemen om problemen te vermijden met betrekking tot de geldingskracht in de verschillende gewesten, die elk hun eigen terminologie zouden hanteren. Ook teksten bedoeld voor een bepaalde groep personen van een bepaalde stad hanteren immers dergelijke constructies $\left({ }^{29}\right)$.

Deze bevindingen worden ook gestaafd door de geschriften van zeventiendeeeuwse juristen. In de Introductio van zijn Notitia iuris belgici waarschuwt Van Den Zype ( ${ }^{30}$ ) niet te vertrouwen op de benamingen edictorum, constitutionum, ordinationum, placitorum, decretorum, rescriptorum (quae omnia nomina Edictorum comprehendemus). Telkens weer moet per tekst vastgesteld worden, vooral aan de hand van de aanspreking en de epiloog met bevel tot publicatie, of de tekst generaal of particulier is, blijvend of provisioneel.

Naast de vraag of er afgelijnde onderscheiden zijn tussen de gebruikte termen, is het ook belangrijk even stil te staan bij de vraag of er een evolutie is in het gebruik ervan. Binnen de onderzochte periode (zestiende-zeventiende eeuw) stellen we geen opvallende verschuivingen vast in de terminologie. Een vergelijking met de vorige eeuwen getuigt echter wel van een evoluerend wetsconcept. De juristen van de centrale ambtenarij putten uit het termenmateriaal van het Romeinse recht om de absolutistische staat en zijn verschijningsvormen te beschrijven. Uit de benaming van de wetgeving blijkt duidelijker dan vroeger een bevelskarakter $\left.{ }^{31}\right)$. De soevereine wilstheorie wordt steeds sterker uitgebouwd en dit uit zich in de benamingen van de wetgevende akten. Octrooien, instructies, confirmaties, sententies, reglementen, charters en akten worden steeds schaarser, hoewel ze nooit helemaal verdwijnen. In de plaats komen steeds meer akten onder de naam ordonnantie, die duidelijk het bevelskarakter van de tekst uitdrukt, wat blijkt geeft van een fundering op de lex regia. En verder zijn er meer en meer edicten, decreten, rescripten of mandaten. De Romeinse invloed is overduidelijk. In de Romeinse wetgeving vinden we immers precies deze termen terug. Keizerlijke edicten hebben een algemene draagwijdte en onbeperkte geldingsduur. Decreta zijn uitspraken van de keizer als opperste rechter. Met rescripten geeft de keizer als opperste jurist

(28) Zie o.a. J. Yernaux, Les notaires publics du $x \|^{\circ}$ au $x v t^{e}$ siècle, spécialement au Franc de Bruges, in Bulletin de la Commission Royale d'Histoire, LXXXII, 1913, p. 111-182, voornamelijk p. 128.

(29) Voor wat Brussel betreft bijvoorbeeld, kunnen we verwijzen naar de vaststellingen van P. Gomdin(;, Liste chronologique provisoire des ordonnances intéressant le droit privé et pénal de la ville de Bruxelles (1229-1657), in Handelingen van de Koninklijke Commissie voor de Uitgave van de Oude Wetten en Verordeningen van België, XVII, 1950-1953, p. 339-400, vooral p. 360.

(30) F. Zyparus, Notitia iuris belgici, Antwerpen, 1675, p. 1-3. Op p. 16-19 wijdt de auteur een hoofdstuk aan de wetgeving.

(31) Zie hierover Monnhaupt, Potestas legislatoria und Gesetzesbegriff im Ancien Regime, in lus Commune, IV, 1972, p. 188-239. 
antwoorden op vragen uit de praktijk. Mandata tenslotte zijn administratieve richtlijnen van de keizer aan zijn ambtenaren.

Dat er daarenboven bij de wetgever en de rechtsgeleerden een zeker gevoel voor duidelijke taal en een vraag naar concreet gedefinieerde termen ontstaat, blijkt ook uit een aantal wetteksten hieromtrent. Op 18 maart 1620 vaardigen de aartshertogen een verklaring uit betreffende artikel 12 van het Eeuwig Edict van 12 juli 1611. Dit artikel schrijft de testamentsformaliteiten voor in de streken waarvoor nog geen costume "gestatueerd" is (nederlandse tekst) of „decreté" is (franse tekst). „Decreteren” slaat op de homologatie door de vorst, de officiële vastlegging en goedkeuring door het centrale bestuur. „Statueren” daarentegen is een veel bredere term. Een dergelijke vaststelling van de costume kan uitgaan van de lokale magistraat, van een rechtbank, eventueel via een turbenonderzoek. Welnu, de Franse tekst is de authentieke. Ook in de gebieden waar uitsluitend de nederlandse tekst wordt afgekondigd, zal "ghestatueert" dus moeten verstaan worden als ,ghedecreteert" ${ }^{(32}$ ).

De stellingen en verklaringen die we tot hiertoe geformuleerd hebben, zullen we nu toetsen aan een concreet voorbeeld. Is er een wezenlijk verschil tussen een „edict" en een „eeuwig edict" ? Op deze vraag vinden we weinig elementen van antwoord. Vooreerst leert het Romeins recht een en ander. Ten tweede zullen we beide typen vergelijken naar vorm en inhoud. Gilissen telde 102 al dan niet eeuwige edicten, waarvan het gros uit de regeringsperioden van Karel V en Jozef II. Het zijn er echter ongetwijfeld veel meer. Albrecht en Isabella alleen al vaardigden er een veertigtal uit. In de vijftiende eeuw vinden we weinig of geen sporen van edicten, eeuwige noch gewone ${ }^{33}$ ). Vooral de term „eeuwig edict” lijkt pas redelijk laat zijn intrede te doen en beleeft een heropbloei in de keizerlijkc ambtenarij. Cauchies telde er enkele in de boergondische periode, maar het zijn rariteiten. Ook in het prinsbisdom Luik wordt de term zeer schaars gebruikt. De voorbeelden die we vinden, gaan daarenboven uit van de Keizer ${ }^{(34)}$.

(32) Zie J.-B. Christyn, Brabandts recht, dl. 2, p. 1182.

(33) In de regeringsperioden van Filips de Stoute, Margaretha van Male en Jan zonder Vrees (1381-1419) vinden we deze terminologie niet terug. Zie P. Boninrant, J. Bartier en A. Van Nieuwenhuysen (ed.), Recueil des ordonnances des PaysBas, reeks 1, afd. 1, dl. 1, Brussel, 1965 en A. VAn Nifumenhursin (ed.), eod., dl. 2, Brussel, 1974. Als representatief staal voor de rest van de vijftiende eeuw verifieerden we J.-M. Cauchits, Liste chronologique provisoire des ordonnances de Philippe le Bon, duc de Bourgogne, pour le comté de Hainaut (1425-1467), in Handelingen van de Koninklijke Commissie voor de Uitgave der Oude Wetten en Verordeningen van België, XXVI, 1973-1974, p. 35-146 en Liste chronologique des ordonnances de Charles le Hardi, Marie de Bourgogne, Maximilien d'Autriche et Philippe le Beau pour le comté de Hainaut (1467-1506), eod., XXXI, 1982-1984, p. 1-125.

(34) Op 20 oktober 1530 bevestigt de keizer de aloude costume dat de Luikse schepenvonnissen in crimincle zaken uitvoerbaar zijn en niet geschorst kunnen worden 
Enkele „eeuwige edicten" hebben een bijzondere faam verworven. Voor (publiekrechts)historici is hét Eeuwig Edict dat van Marche-en-Famenne van 12 februari 1577. De landvoogd don Juan van Oostenrijk bevestigt erin de Pacificatie van Gent van 1576, belooft de vreemde troepen uit de Nederlanden terug te trekken en de oude privileges te erkennen ( $\left.{ }^{35}\right)$. Hét Eeuwig Edict voor (althans Zuidnederlandse) privaatrechtshistorici is ongetwijfeld dat van 12 juli 1611, gegeven te Mariemont. De aartshertogen Albrecht en Isabella vernieuwen ermee in de eerste plaats en met aandrang het bevel tot codificatie en homologatie van de costumen. Daarnaast worden enkele materies van erf-, bewijsen testamentair recht behandeld, alsook enkele aspecten van gerechtelijk en strafrecht. Aangezien de noordelijke Nederlanden in 1611 de facto al onafhankelijk zijn, heeft dit edict daar nagenoeg geen weerklank. In vele Nederlandse rechtshistorische handboeken vinden we als hét Eeuwig Edict daarom, dat van 4 oktober 1540. Dit handelde ook over verschillende onderwerpen, zoals ketterij, monopolievorming, faillissement, homologatie van costumen, vijgevigheden door minderjarigen, benoeming van lokale magistraten, ... ( $\left.{ }^{36}\right)$.

Waarom verdient een bepaald edict nu het etiket „eeuwig”? Alle wetten zijn toch, tenzij uitdrukkelijk anders bepaald, bedoeld om lange tijd te gelden, tot ze uitdrukkelijk of stilzwijgend worden opgeheven of door onbruik teniet gaan ( $\left.{ }^{37}\right)$ ? Wellicht moeten we een eerste element van antwoord zoeken in het Romeins recht. De universitair geschoolde hoge ambtenaren van de centrale regering hadden bijna uitsluitend het Romeinse recht gestudeerd $\left({ }^{38}\right)$.

door beroep bij hogere instanties : nos, considerantes constitutiones et consuetudinem praedictam (...) bonam, sanctam et rationabilem esse, eandem auctoritate nostra imperiali duximus confirmandam et approbandam, hoc irrefragabili et perpetuo statuentes edicto, ne ... Zie L. Poi aIN (ed.), Recueil des Ordonnances de la Principauté de Liège, reeks 2, dl. 1, Brussel, 1869, p. 76-78.

(35) De bepalingen in verband met de godsdienstvrijheid, door de opstandige nederlandse gewesten in de Pacificatie van Gent afgedwongen, werden echter niet in het edict opgenomen. Zie o.a. P. Pestiaux (ed.), 1577-1977. Marche et l'Edit Perpétuel. Catalogue de l'exposition du 400' anniversaire de la signature de l'Edict perpétuel, Andenne, 1977 en G. JANSSENS, "Brabant in het Verweer". Loyale oppositie tegen Spanje's bewind in de Nederlanden van Alva tot Farnese. 1567-1578, Kortrijk-Heule, 1989 (Standen en Landen, LXXXIX), p. 317-349.

(36) Tekst in J. Lameerf en H. Simont (ed.), Recueil, reeks 2, dl. 4, Brussel, 1907, p. 232-238. De invloed op het nederlandse recht wordt o.a. besproken in A. Kunst, Historische ontwikkeling van het recht, dl. 2, Zwolle, 1968, p. 62, 474 en 526.

(37) $\mathrm{Bij}$ dit laatste kunnen we ons echter afvragen of dit in ons oude recht hoedanook denkbaar was. Het vigerend recht werd immers aanzien als een vaststaand geheel, een continuum dat onmerkbaar of niet evolueerde.

(38) Dr: Montrifinchamp schrijft in zijn Histoire de l'archiduc Albert, Brussel, 1870 , p. 525 dat Albrecht in zijn streven naar codificatie en unificatie van de costumen een 'eeuwig edict' wilde tot stand brengen naar het voorbeeld van het Edictum Perpetuum van de Romeinen. Wellicht gaat het hier om een beoordeling post factum door de historicus en niet om een expliciete beweegreden van de aartshertog. 
Pas vanaf de zeventiende eeuw veroveren costumier en wettenrecht druppelsgewijze een plaatsje in het universitaire curriculum $\left({ }^{39}\right)$. In het bestudeerde antieke recht nu komen de termen edictum en edictum perpetuum herhaaldelijk voor. Elke magistraat heeft er binnen zijn ambtsdomein het ius edicendi, de bevoegdheid om bindende beschikkingen te treffen. Het meest markante voorbeeld is het jaarlijkse edict van de praetor, de magistraat die instaat voor de rechtsbedeling. Bij het begin van zijn ambtstermijn maakt hij bekend welke rechtsmiddelen (acties, excepties en interdicten) hij zal verlenen. Via deze formele voorschriften geeft hij vorm aan het vigerende recht. Dergelijke edicten worden edicta annua of ook wel perpetua genoemd omdat ze bedoeld zijn een hele ambtstermijn, dit is één jaar, mee te gaan. Andere edicten echter zijn slechts eenmalige mededelingen en ambtsbevelen, zijn toegespitst op een zeer concrete toestand en hebben dan ook een beperkte geldingsduur. Edictum perpetuum kan in het Romeinse recht ook duiden op één wel bepaald edict uit het begin van de tweede eeuw. Daar de praetoren meestal de goede bepalingen van hun voorgangers overnemen, ontstaat een vaste kern van rechtsregels, die ongewijzigd blijft. Dit edictum tra(ns)laticum brengt keizer Hadrianus ertoe aan de jurist Salvius Julianus de opdracht te geven een definitieve versie van het edict op te stellen. Deze wordt door de latere rechtshistorici aangeduid met de term edictum perpetuum. Ook de keizer, de hoogste magistraat, had natuurlijk het ius edicendi. De edicta waren constitutiones principum van algemene gelding en onbeperkte duur, in tegenstelling tot de meer beperkte rescripta, decreta et mandata, zoals hoger reeds werd uiteengezet $\left({ }^{40}\right)$.

Deze romeinse elementen leren ons dus een en ander. „Perpetuum, perpétuel, eeuwig" kan duiden op een betrekkelijk lange (al dan niet op voorhand bepaalde) toepassingstermijn van de wet, de ambtstermijn namelijk van de uitvaardigende magistraat. Paul Van Christijnen schrijft in die zin dat de stadsmagistraat jaarlijks herkozen moet worden en de stedelijke ordonnanties telkens opnieuw uitgevaardigd $\left({ }^{41}\right)$. Wellicht is dit een puur theoretisch inzicht. Er waren tientallen of honderden stadsordonnanties, wat een regelmatige

(39) Voor onze streken was vooral de Leuvense Alma Mater belangrijk. Over het curriculum aldaar, zie V. BRANrs, La faculté de droit de l'Université de Louvain à travers cinq siècles. (Étude historique), Brussel, 1917, p. 150-159, over de professoren en hun colleges p. 207-227 en over de invloed van deze laatstgenoemden op de wetgevende activiteit p. 160-179.

(40) Bekend zijn vooral de Iustiniani XIII edicta quae vocatur, zie R. ScHofl.I en G. Krot.t. (ed.), Corpus luris Civilis, dl. 3, Berlijn, 1928, p. 760-793. Over het Edictum Perpetuum van Salvius Julianus, zie O. Lfvis., Das Edictum Perpetuum : ein Versuch zu seiner Wiederherstellung, Aalen, 1956.

(41) P. Van Christionen, Practicarum quaestionum rerumque in supremis Belgarum curiis actarum et observatarum decisiones, dl. 2, Antwerpen, 1636, p. 66, nr. 3. 
bekendmaking praktisch onmogelijk maakt. Misschien echter beschikten de magistraten over een of andere formule om aan de nog geldende regels te herinneren. Het lijkt alleszins zeer gevaarlijk de these van Christijnen te transponeren op het permanente centrale gezag, dat niet met vaste regelmaat wordt vervangen. Een edict z.ou anderzijds eeuwig zijn omdat het niet bedoeld is voor een korte termijn of om aan tijdelijke omstandigheden te verhelpen. In een derde betekenis zou het „eeuwig zijn" kunnen slaan op het feit dat geen herhaalde uitvaardiging van de wet nodig is om in voege te blijven. Ruimer geïnterpreteerd zou een dergelijke wet moeten ,voort-duren", ook nadat de wetgevende lichamen zelf niet meer aan de macht zijn. Dit moet dan van meet af aan wel de uitdrukkelijke bedoeling van de wetgever geweest zijn. Is dit niet zo en duurt de wet feitelijk langer dan voorzien, dan wordt de wet immers costume ${ }^{42}$ ).

$\mathrm{Bij}$ een dergelijke op voorhand voorzien langdurige wet, is het dus wellicht correcter „perpetuum” of „perpétuel” niet als „eeuwig”, dan wel als „voortdurend" te vertalen. De in de wetteksten gebruikte formuleringen wijzen echter zeer vaak op de bedoeling om eeuwig te gelden, in de zin van lange tijd : „... statuons par ces présentes, par manière de edict perpétuel, ... afin que ceste nostre ... soit doresenavant à tousjours inviolablement gardée, ..." $\left.{ }^{43}\right)$. Een redactie als deze staat heel dicht bij de bewoordingen waarmee al eeuwen lang optekenigen van costumen of verordeningen van lagere overheden werden aangeheven of besloten, zoals bijvoorbeeld : „... dat wi geordineert hebben te houdene te eweliken dagen" $\left({ }^{44}\right)$. Deze wellicht typisch middeleeuwse gedachte van een traag of niet evoluerend eeuwig recht, vinden we ook reeds veel vroeger in de geschiedenis terug. Denken we bijvoorbeeld aan de Ewa ad Amorem. Het is echter ongetwijfeld onder invloed van het Romeins recht dat in de Nieuwe Tijd van alle synoniemen voor wet of verordening nagenoeg alleen edict het epitheton ,eeuwig” krijgt ( $\left.{ }^{45}\right)$.

(42) In de Practycke civile van Phelip WI:I.ANT (Antwerpen, 1573, reprint Amsterdam, 1968, E. STrubib: (ed.), p. 28-29), lezen we: „Eest dat naer t'expireren van eenen statute dat gemaeckt is te tijde, men daeraf blijft useren sonder wederseggen van de volcke, sulcken tyt als van costume te prescriberen, soe werdt dat statuyt costume".

(43) Ordonnantie van 5 augustus 1521 betreffende de dagvaarding van leken voor kerkelijke rechtbanken (C. LAuri:Nr en J. LAMFiri: (ed.), Recueil, reeks 2, dl. 2, Brussel, 1898, p. 96-97).

(44) Brusselse ordonnantie van 11 november 1355 geciteerd door P. Gomminci, Liste chronologique provisoire ..., p. 361, noot 2.

(45) Er zijn nochtans uitzonderingen. Het edict van 21 februari 1528 (1529 n.s.) betreffende o.a. renten en de dode hand is een „ordonnance perpétuelle”, zie J. LAMFFrF (ed.), Recueil, reeks 2, dl. 2, p. 547-549. 
Antonio Anselmo ( ${ }^{46}$ ) formuleert op de eerste bladzijde van zijn commentaar op het eeuwig edict van 1611 twee analoge verklaringen voor de term perpetuum, de ene formeel, de andere materieel. Formeel duidt de term aan dat één publicatie volstaat $\left({ }^{47}\right)$, materieel geeft hij te kennen dat het edict noch temporeel, noch provisioneel is. Een temporele wet geldt voor een termijn door de wet zelf of een andere wet voorgeschreven. Een provisionele wet duurt zolang zijn specifieke ratio duurt. Naast deze formele en materiële verklaring, schrijft de auteur ook nog dat een eeuwig edict in tegenstelling tot een gewoon edict niet door onbruik teniet gaat. Deze op het eerste zicht aantrekkelijke hypothese bouwt Anselmo als volgt wat breder uit. Waar een derogatie door privé-personen bij elke wet al bijna uitgesloten is (tenzij na constant, uniform en langdurig afwijkend gedrag), is voor een eeuwige wet zelfs een onbruikconsensus van de ondergeschikte rechtbanken niet voldoende. Derogatie kan alleen door de hogere rechtbanken en moet daarenboven uitdrukkelijk gebeuren ${ }^{48}$ ). De feiten hebben echter deze eeuwigheidsintenties achterhaald. Eeuwige edicten zijn in onbruik gevallen, andere zijn herhaaldelijk opnieuw uitgevaardigd $\left(^{49}\right)$. Van Den Zype $\left(^{50}\right)$, geeft een analoge, maar ietwat afwijkende verklaring. Eeuwige edicten gaan volgens hem niet door onbruik (non usum) teniet, maar wel door tegengesteld gebruik (usum contrarium). Verder weidt hij er echter niet over uit.

In de regeerperiode van Keizer Karel $\mathrm{V}$ vinden we enkele edicten die Anselmo's verklaring in principe staven, maar er meteen een uitzondering

(46) Anselmo (1598-1668), advocaat, stadsmagistraat en rechtsgeleerde is één van de belangrijkste uitgevers en commentatoren van de wetgeving uit de onderzochte periode. Hij schreef de meest uitgebreide bespreking van het Eeuwig Edict van 12 juli 1611 : Commentaria ad perpetuum edictum serenissimorum Belgii principum Alberti et Isabellae, evulgatum 12 julii 1611, Antwerpen, 1656, 1664, 1701 en 1711. Wij gebruikten de oudste versie. Hoewel latere auteurs Anselmo niet als een groot wetenschapper afschilderen, worden zijn werken door doctrine en rechtspraak herhaaldelijk geciteerd.

(47) Aangezien er echter bepaalde ,perpetuele" edicten toch een bevel tot herpublicatie inhouden, moeten we besluiten dat het materiële element sterker weegt dan het formele. (cfr. infra).

(48) Anselmo verwijst ter staving naar Consilium 10, nummer 2 van E. Leovivus, Centuria Consiliorum, Antwerpen. 1584. Daarin wordt echter gesteld dat als een geval dat door de wettekst beoogd wordt, zicht niet voordoet, de wet toch geldig blijft. De uitbreiding van deze hypothese tot ons verklaringsmodel gaat iets te ver.

(49) Een eeuwig edict betreffende de paardenhandel van 31 mei 1556 wordt op 14 maart 1559 opnieuw, en weer in de vorm van eeuwig edict, uitgevaardigd. Op 27 juni 1559 volgt nog eens een oproep dit na te leven, deze keer echter niet in de vorm van een eeuwig edict. Zie C. Teri.INIDEN en J. Bolsfi: (ed.), Recueil, reeks 2 , dl. 7 , p. 89 en 419.

(50) F. Zypafus, Notitia iuris helgici, Antwerpen, 1675, p. 1. 
op vormen. In een edict van 22 september $1540\left(^{51}\right)$ bijvoorbeeld vaardigt de keizer nieuwe maatregelen uit tegen de ketters. In paragraaf 2 wordt verwezen naar ,... diveersche edicten ende ordonnancien (die wy voortyts) gemaect ende gestatueert hebben, ...", maar waaraan blijkbaar geen gevolg meer werd gegeven. Om dit in onbruik vallen tegen te gaan beveelt de keizer dan ook „... allen onsen rechteren ende officieren neerstich toesich ende sorghe te dragene tot onderhoudenisse ende observacie van onsen brieven van placcate hierop geexpedieert ende gepubliceert, sonderlinge de publicatie van dien te vernyeuwen van zesse maenden te zesse maenden, ten eynde dat nyemant daeraf ignorancie pretenderen en soude". Na deze herhaling van oude voorschriften neemt de keizer nieuwe maatregelen in de vorm van ,edict ende eeuwige wet” (paragraaf 3) en ,gebot ende eeuwighe wet" (paragraaf 4). Gezien dit eeuwigheidskarakter zou een enkele publicatie in principe nu moeten volstaan. Het hete hangijzer van de ketterij blijkt echter zo brandend dat in paragraaf 16 de herhaalde publicatie toch wordt voorgeschreven ( $\left.{ }^{52}\right)$. In de loop van de tweede helft van de zestiende eeuw worden deze en andere maatregelen ter vrijwaring van het ene en ware katholieke geloof daarenboven verschillende keren in nieuwe ordonnanties opgenomen ( ${ }^{53}$ ). Zowel het argument van de enige afkondiging als dat van de onmogelijkheid van derogatie worden dus weerlegd $\left({ }^{54}\right)$. Het epitheton „eeuwig” houdt dan nog als voor-

(51) J. Lameere en H. Simont (ed.), Recueil, reeks 2, dl. 4, Brussel, 1907, p. 224 229.

(52) „Ende hoe wel dat onze meyninghe is dat onse tegenwoirdighe ordonnancie zal in eeuwicheden onderhouden worden, ende dat nyet van noode en zy die anderwerven te publiceren na d'eerste publicatie, nochtans, om dat nyemant daeraf gheen ignorancie en pretendere, sonderlinge die vuytlanders ende jongelieden wy willen dat van sesse maenden te sesse maenden, te wetene, op Sint Jans Baptisten ende Kersavont, by allen officieren van de principale steden van onsen lande ende graefscepe van Vlaenderen ende van d'ander plaetsen daer men gewoonlick is vuytroepinghe ende publicatie te doene, die voorscreven publicatie ghedaen ende ververscht worde, opte peyne van thien gouden karolus ...".

(53) Bijvoorbeeld het keizerlijk edict van 29 april 1550, gegeven te Brussel: „Ordonnance, statuut ende eeuwich edict om textirperen ende te nieten te brynghen die secten ende erreuren opgheresen teghen onsen heyligen kersten gheloove, ... met den catalogue van den ghereprobeerden ende verboden boucken, ...". Zie J. LAMEERE (ed.), Recueil, reeks 2, dl. 6, Brussel, 1992, p. 55-63 : „... verbieden, interdiceren, ordineren ende statueren voir eeuwich gebot ende wet tgene des hier na volgt ...", "Ende hoewel onse meyninge $z y$ dat onse ieghewoirdige ordinancie eeuwige ende perpetuele zy, ende dat van gheenen noode en es de selve wederomme te doen publicere ende uuytroepen ... nochtans ... wy willen dat van sesse te sesse maenden ... de voirscreven publicatie ververscht (...)".

We staan hier eigenlijk voor een voorbeeld bij uitstek van de divergentie tussen het „wettelijke” en het „werkelijke land”. De vorst zelf erkent dat zijn wil niet steeds waarheid wordt.

(54) Het is belangrijk nog te onderstrepen dat de herhaalde publicatie erop gericht is de wetsonwetendheid te voorkomen. De intrinsieke juridische waarde hangt dus 
naamste betekenis over het belang van de behandelde materie te onderstrepen. De ketterij tastte in dergelijke mate de publieke orde van de maatschappij aan, dat de kerk, als van wezenlijk belang voor de openbare orde, ten eeuwigen dage moest beveiligd worden ( ${ }^{55}$ ).

Ook in zijn Tribonianus (56) weidt Anselmo uit over de term perpetuum naar aanleiding van de bespreking van het eeuwig edict van 25 juni 1601 , waarin de munt bepaald wordt waarmee oude en recente rentecontracten kunnen teruggekocht worden. Als nieuw verklaringselement haalt hij het principe princeps legibus (ab)solutus aan en spijst dit met tal van digestencitaten. De hoogste instantie kan ex definitione zelf niet aan een hogere macht onderworpen zijn. Evenmin kan hij zich daarom verbinden om niet op door hemzelf uitgevaardigde wetten terug te komen. Een edict dat eeuwig zou voortduren, ondanks de veranderde wil van de wetgever, is op de grond van deze maxime dan ook onmogelijk. Daar nu echter in principe elke wet voortduurt tot de uitvaardiger of zijn opvolger hem herroept, zijn alle edicten eeuwig. Anselmo komt ook zelf tot dit besluit $\left({ }^{57}\right)$. We mogen hieruit dus besluiten dat deze auteur in de terminologie niet veel meer zag dan een estethische toevoeging, die geen juridische gevolgen had. Hooguit werden ermee het belang van de behandelde rechtsinstellingen en juridische regels en de intentie van de wetgever onderstreept $\left({ }^{58}\right)$. Zijn er dan ook nog andere bijvoeglijke naamwoorden gebruikt om hieraan uitdrukking te geven? Ja, de bijzondere intentie van de wetgever wordt vaak nog met andere epitheta aangeduid. Zo zijn er „politieke" edicten $\left({ }^{59}\right)$, ,publieke" edicten $\left({ }^{(6)}\right)$ en zelfs ,goddelijke” edicten $\left({ }^{61}\right)$.

niet af van de herhaalde publicatie. Ook zonder tweede publicatie blijft de wet van kracht.

(55) Zo lezen we in paragraaf 18 van het hier behandelde edict: "Alle welcke poincten ende articulen wy willen ende ordonneren onverbrekelick teeuwighen dagen als voren onderhouden ende geobserveert te worden naer huere vorme ende inhouden, (...)".

(56) A. Anseimo, Tribonianus Belgicus sive dissertationes forenses ad belgarum principum edicta, Brussel, 1658, p. 270-284.

(57) Hij vergelijkt met een contract van eeuwigdurende rente, dat voortduurt tot het kapitaal wordt teruggekocht.

(58) De intentie van de wetgever in het geval van een „eeuwig edict”, zou dan zijn een wet uit te vaardigen die zolang zou gelden als hij dat wil.

(59) Zie bijvoorbeeld het edict van 20 maart 1601 over aanmaak, verkoop en verbruik van gedistilleerde dranken (V. BRANTS (ed.), Recueil, reeks 2, Règne d'Alhert et Isabelle (1597-1621), dl. 1, p. 139-140) : „par forme d'edict politicque en l'usage dudict brandwyn".

(60) Het edict van 1 oktober 1520 over de tienden bijvoorbeeld (J. LAMFi:Ri: (ed.), Recueil, reeks 2, dl. 2, p. 23-25): „par forme de constitution et edict publique et perpetuel".

(61) Edict tegen de Lutherse ketterij van 8 mei 1521 (C. LAURint et J. LAMFiri: (ed.), Recueil, reeks 2, dl. 2, p. 73-83, citaat p. 80) : „Alles achtervolghende die costumen 
Gaat het inderdaad steeds om belangrijke voorschriften? Een steekproef van acht eeuwige edicten van Albrecht en Isabella betreft volgende onderwerpen: de Antwerpse beurs en haar handelaars $\left({ }^{62}\right)$, de muntwaarde bij rentecontracten $\left({ }^{63}\right)$, de dijken $\left({ }^{64}\right)$, de vagebonden $\left({ }^{65}\right)$, de goudsmeden $\left({ }^{66}\right)$, het duel $\left({ }^{67}\right)$, de homologatie van costumen en enkele aspecten van privaat- en gerechtelijk recht $\left({ }^{68}\right)$, moordpreventie en -repressie $\left({ }^{69}\right)$. Het gaat met andere woorden naar moderne terminologie om materies van handels-, straf-, burgerlijk, gerechtelijk en administratief recht. Binnen elke rechtstak gaat het daarenboven niet om de meest belangrijke aanlegenheden $\left({ }^{70}\right)$, noch om een exhaustieve regeling van een heel vakgebied. De meeste edicten regelen daarenboven verschillende onderwerpen, die intrinsiek weinig met elkaar te maken hebben. Dit noopt ons er dan ook toe de belangrijkheid van de geregelde materie als criterium om het „eeuwigheids-etiket” op te kleven, niet als doorslaggevend te beschouwen. Met de materie is ook nauw de omvang van de doelgroep verbonden. De onderzochte edicten zijn niet steeds voor de hele bevolking bestemd, maar vaak voor heel specifieke sociale groepen, de handelaars van de Antwerpse beurs bijvoorbeeld.

Binnen de onderzochte edicta perpetua vinden we wel andere constanten. Alle gaan ze uit van de aartshertogen (zoals ze in de voorgaande periode alle uitgingen van de keizer of de koning), al wordt de wet al dan niet op

ende rechten gheestelick ende weerlick ende goddelicke edicten, uutghegheven gheboden teghen dieghene die in ketterie, ...".

(62) V. Brants (ed.), Recueil, dl. 1, Brussel, 1909, p. 131-133: Ordonnantie van 16 januari 1601.

(63) Eod., p. 149-150: ordonnantie van 25 juni 1601.

(64) Eod., p. 184-185: edict van 8 augustus 1602.

(65) Eod., p. 353-356: plakkaat van 3 augustus 1607, verwijzend naar de eeuwige edicten van Karel V van 3 februari 1542 (1543 n.s.) en 11 april 1540 (1541 n.s.) over. dezelfde materie.

(66) Eod., p. 360-367 : edict van 20 oktober 1607. Dit edict interpreteert en verbetert het eeuwig edict van 13 april 1551 .

(67) Eod., dl. 2, p. 41-43 : edict van 27 februari 1610. In juni 1557 was ook al een eeuwig edict over het tweegevecht uitgevaardigd, zie C. TERI INIDEN en J. Bol.SFe (ed.), Recueil, reeks 2, dl. 7, p. 209.

(68) Het „Eewich Edict tot beter directie in saecken van Justitie in de landen van Herwaertsover" en zijn latere interpretaties zijn niet door BRANTS in zijn uitgave opgenomen. Ze moesten een apart deel vormen, dat helaas nooit werd gerealiseerd. We vinden de tekst in de reeksen plakkaten van Vlaanderen en Brabant alsook bij ANSEI.MO, zie noot 46.

(69) V. Brants (ed.), Recueil, dl. 2, p. 288-295 : edict van 1 juli 1616.

(70) Tijdens de regering van Filips II betroffen de eeuwige edicten vooral de landloperij en verder de paardenhandel, de visvangst in bepaalde wateren, de handel via rivieren in Zuid-Holland, de duivenvangst in Friesland, de jutrechten op overstroomde gronden nabij Dordrecht. 
rekwest gegeven of met advies van verschillende instellingen $\left({ }^{71}\right)$. Logisch gezien heeft alleen de hoogste instantie de macht om voort-durende wetgeving uit te vaardigen. Indien de wet uitgaat van een lagere legifererende macht, kan een hogere die wijzigen of afschaffen. Wordt de wet echter gegeven door de hoogste macht, dan kan alleen dezelfde macht (of haar rechtsopvolger) die wet herroepen. Misschien mogen we in de gebruikte terminologie dan ook een expressie zien van de onafhankelijkheid van de Nederlanden onder de aartshertogen ten opzichte van de Spaanse kroon. Hoger stelden we ook al vast dat het gros van de al dan niet eeuwige edicten afkomstig is van de keizers Karel V en Jozef II.

Een andere constante betreft de preambule van elk onderzocht edict. Keer op keer wordt er verwezen naar vroegere wetgeving over de geregelde aangelegenheden. Soms gebeurt dat in abstracte termen $\left({ }^{72}\right)$, maar meestal worden oude wetten naar onderwerp en datum geciteerd ( ${ }^{73}$ ). Een dergelijke redactie roept onvermijdelijk het beeld op van de dreigende schoolmeester : „Ik zeg het u nu voor de laatste keer, voor eens en altijd !”. Deze redactie mogen we echter niet exclusief aan eeuwige edicten toekennen, ook tal van andere wetten verwijzen naar oudere akten. Alweer mogen we dus behalve een zekere intentie en persoonlijke appreciatie van de wetgever, geen juridische gevolgen toeschrijven aan de term perpetuum.

Evenmin vinden we discriminatoire elementen in formele criteria als de diplomatieke vorm van de akte en de publicatie. De formulering in de wetgevende akte doet nochtans vermoeden dat het onderscheid al dan niet eeuwig vooral een vormverschil is : „par forme de loy et édict perpétuel” ( $\left.{ }^{74}\right)$, „by forme van declaratie ende eeuwich edict" $\left({ }^{75}\right)$, „ordonnons et statuons par formc d'ćdict perpétuel” $\left({ }^{76}\right)$, ,by vorme van eeuwich edict" $\left({ }^{77}\right)$. Wat het diplomatieke kleedje betreft, onderscheidt een eeuwig edict zich echter niet van

(71) We baseren ons hier uitsluitend op de teksten zelf en de daarin gebruikte formules (voornamelijk in de aanhef). Het is echter niet uitgesloten dat ook wanneer er geen uitdrukkelijke melding wordt van gemaakt, er toch voorafgaande adviezen of rekwesten zijn geweest.

(72) Zo verwijst de ordonnantie van 25 juni 1601 naar de vele disputen die zich voordoen omtrent de onduidelijkheden in de bestaande regeling. In de inleiding van het edict van 8 augustus 1602 wordt beweerd dat men zijn plichten wel kent, maar ze niet vervult.

(73) Zo verwijst het edict van 20 oktober 1607 naar meerdere oude plakkaten, maar vooral naar de ordonnantie van 13 april 1551. Ook de wet van 1 juli 1616 verwijst naar oude wetgeving. Het eeuwig edict over het duel heeft het over ,... grand mépris des loix divines et humaines".

(74) Edict van 25 juni 1601 , cfr. supra.

(75) Edict van 8 augustus 1602, cfr. supra.

(76) Edict van 20 oktober 1607 , cfr. supra.

(77) Edict van 1 juli 1616 , cfr. supra. 
andere ordonnanties. De publicatie dan, zou volgens Anselmo eenmalig zijn in tegenstelling tot andere edicten die herhaaldelijk gepubliceerd worden. Zo beweert deze auteur dat edicten over munten elk trimester opnieuw uitgevaardigd worden en edicten over vagebonden elk jaar. We stellen echter vast dat bepaalde eeuwige edicten halfjaarlijks opnieuw worden afgekondigd. Daarenboven vinden we geen constante in de uitdrukkelijke voorschriften tot herhaalde publicatie in verband met munten en landloperij. Wel zijn dit onder Albrecht en Isabella twee zeer populaire onderwerpen van wetgeving. Tal van verordeningen volgen elkaar op. De iure echter gaat het dan telkens om andere edicten. Een constante herhaling van alle (niet-eeuwige) edicten lijkt ons daarenboven alleen al praktisch gezien ondoenbaar, gezien het immense aantal wetgevende akten dat zich op dat moment al geaccumuleerd heeft. De drukkunst heeft er ook al bijna twee eeuwen evolutie op zitten, zodat een herhaalde publicatie als kenniskanaal een kleinere rol zou moeten krijgen.

Tot hier hebben we slechts weinig specifieke kenmerken kunnen vaststellen, die een eeuwig edict onderscheiden van een doorsnee-edict, zijnde een wet met algemene strekking uitgaande van de hoogste macht. Niettemin vinden we andere wetgevende akten die we als antipoden van eeuwige edicten kunnen aanzien. Edicten staan als algemene rechtsregels natuurlijk tegenover specifieke voorrechten of privileges. Dit neemt niet weg dat vele privileges ook het epitheton „eeuwig” krijgen. Het gaat daarbij meestal om de eenzijdige belofte vanwege de soeverein bestaande voorrechten in de toekomst niet (meer) te zullen schenden $\left({ }^{78}\right)$. De koppeling van de termen privilege en eeuwig dateert al uit een vroegere periode, we vinden talrijke voorbeelden in de Boergondische tijd ${ }^{(79)}$. Naast wetten en privileges krijgen ook bijvoorbeeld verdragen $\left(^{80}\right)$ het bijvoegsel „eeuwig, perpétuel, perpetuum". Al deze verschillende soorten akten nu hebben beperkte, tijdelijke tegenhangers. Zo worden bepaalde plakkaten

(78) Zie bijvoorbeeld de toezegging aan de Brusselse glasblazers van 26 juni 1599 (V. Brants (ed.), Recueil, dl. 1, p. 68-69:, ,Si donnons en mandement à noz très chiers et feaulx ... que ... ilz ... laissent lesdits supplians, présens et advenir plainement, paisiblement et perpétuellement joyr et user, ...". In het edict van 11 september 1602 over de Brugse wolhandelaars lezen we : „... octroyons, ordonnons et statuons par ces présentes, par forme de privilege perpétuel ..." (eod., p. 187-189). Soms zijn privileges ipso facto eeuwig omdat ze vastgelegd worden in de vorm van een contract tussen de justiciabelen en de vorst, zie hierover o.a. F. Zypaeus, Notitia iuris belgici, Antwerpen, 1675, p. 3.

(79) Zie bijvoorbeeld : J. Granidiagnage (ed.), Coutumes de Namur, dl. 1, Brussel, 1869, 299: Maria van Boergondië bevestigt enkele oude Naamse privileges: „Si donnons en mandement ... par fourme d'ordonnance et privilége perpétuel, ...".

(80) De verordening van 16 oktober 1604 beveelt de publicatie van de vrede met Engeland en omschrijft deze als "confédération et perpétuelle ailliance" (V. BRANTs, (ed.), Recueil, dl. 1, p. 254-255). 
uitgevaardigd „par manière de provision” $\left({ }^{81}\right)$ of „bij manieren van provisie” $\left({ }^{82}\right)$. Telkens gaat het dan om zeer tijdelijke situaties waaraan verholpen wordt : restauratie van kerken $\left({ }^{83}\right)$, beperking van de duivenkwekerij $\left({ }^{84}\right)$, audit van de rekeningen ( ${ }^{85}$ ). Zodra de tijdelijke ratio van de wet ophoudt te bestaan, houdt ook de geldingskracht van de wet op. Cessante ratione legis, cessat lex. Het provisionele van de verordening kan ook liggen in de mogelijkheid die de wetgever zich reserveert op zijn stappen terug te keren $\left({ }^{86}\right)$. Hij stelt dan zijn eigen macht veilig voor de toekomst $\left({ }^{87}\right)$. Vaak zelfs bepaalt de wetgever dat het om een soort proefwetgeving gaat die zolang zal gelden als ze goed blijkt ${ }^{(88)}$. Van Den Zype $\left(^{89}\right)$ beweert dat de vorst op deze wijze poogt om in dubieuze situaties zichzelf veilig te stellen en zich het voordeel van de twijfel te gunnen.

Uit wat voorafgaat kunnen we besluiten dat een edict, een ordonnatie, een plakkaat,... een vorm van wetgeving is met algemene strekking, die haar grondslag vindt in de soevereiniteit van de vorst. In tegenstelling tot privileges of octrooien schrijven ze gedragsregels voor aan een bepaalde (grote) groep, die qua omvang kan variëren: van alle inwoners van alle provincies bijvoorbeeld tot alle goudsmeden van een bepaalde stad. Naar tijdelijke gelding kunnen ze "provisioneel" of ,eeuwig" zijn, naargelang de wetgever ze bedoelde als tegemoetkomingen aan tijdelijke situaties of als beleidslijnen voor de toekomst. Vaak duidde hij dit laatste uitdrukkelijk aan in de benaming van de wet, meestal echter niet. We moeten dan in de tekst zelf, voornamelijk inleiding en slot, de bedoeling van de wetgever zoeken. Zo lezen we in een

(81) Het plakkaat bijvoorbeeld van 24 juli 1599 tegen de misbruiken in de handel van franse wijnen (Eod., dl. 1, p. 71-73). Dit 'placard' wordt in de tekst zelf 'édict' en 'ordonnance' genoemd en bepaalt te gelden 'par manière de provision'.

(82) Een verordening van 24 december 1612 beveelt het houden van duiven te beperken omwille van de schade die ze aanrichten (Eod., dl. 2, p. 158-159) : 'ordonneren ende statueren by desen, bij manieren van provisie, dat ....

(83) Reglement van 28 maart 1611, Eod., dl. 2, p. 78-79.

(84) Zie noot 82.

(85) Reglement van 9 mei 1613, Eod., dl. 2, p. 172.

(86) In de ordonnantie van 14 oktober 1600 over de bescherming van de bossen in de provincie Namen (Eod., dl. 1, p. 107-114) lezen we bijvoorbeeld : "Le tout par provision, tant et jusques a ce que aultrement en sera par nous ordonné, réservans a nous et a noz successeurs, contes et contesses de Namur, de le pouvoir changer, augmenter ou diminuer, selon que l'occasion le requerra".

(87) Een charter van 14 juni 1603 (Eod., dl. 1, p. 213-216) bepaalt : „,... le tout néanmoins par provision et sans préjudice de nos droitz, haulteur et jurisdiction".

(88) Een verbod van 13 april 1601 (Eod., dl. 1, p. 141) geldt „by vorme van provisie ende preuve". In een verordening van 15 februari 1620 (Eod., dl. 2, p. 463) lezen we : „statuons et ordonnons par forme d'essay et tant et jusques a ce que par nous aultrement en soit ordonné".

(89) F. Zypalus, Notitia iuris belgici, Antwerpen, 1675, p. 2. 
keizerlijk edict van 8 mei 1521 : „Des toorconden, ende ten hende dat dit zy vaste ende ghestandich, gheduerich ende eeuwich, hebben wy onsen grooten zeghele hieran doen hanghen, ende tselve mandement ende voorghebodt gheteekent met onser hant" $\left({ }^{90}\right)$. Wanneer de wetgever zelf uitdrukkelijk het epitheton „eeuwig” gebruikt, wijst dit ongetwijfeld op een bijzonder belang dat hij aan de behandelde materie wil hechten. Daar de wettekst wordt opgesteld in de Geheime Raad waarin tal van rechtsgeleerden zetelen, ligt het voor de hand dat deze de hun bekende antieke terminologie hanteren: Edictum Perpetuum. Juridisch betekenen deze teksten dan niet meer dan andere wetteksten. Of ze feitelijk voor het recht en haar geschiedenis van groter belang zijn dan andere verordeningen, wordt bepaald door de tekstuitgever(s), de practici en de wetgever zelf of zijn opvolger. Zo zien we met betrekking tot het eeuwig edict van 12 juli 1611 dat het uitgegeven wordt onder de uitdrukkelijke hoofding „Eeuwich Edict”, dat Anselmo er onder deze naam een uitgebreide commentaar op schrijft, dat hij onder deze naam ingeroepen wordt voor de rechtbanken tot laat in de negentiende eeuw en dat de Aartshertogen, de Koning en de Geheime Raad er tientallen interpretaties en aanvullingen op geven gedurende de hele zeventiende eeuw. Van alle eeuwige edicten is het nagenoeg het enige dat, zijn naam waardig, gegolden heeft in de eeuwen der eeuwen.

(90) Zie J. Lameere (ed.), Recueil, reeks 2, dl. 2, Brussel, 1898, p. 73-83. Hoger in dezelfde tekst werden de behandelde voorschriften ook al genoemd: "dit ons teghenwordich bevel”, „desen onsen edicte ende mandemente”, „desen onsen brieven ende jeghenwoordich decreet ende mandement". 